\title{
ЗАБЕЗПЕЧЕННЯ ДУХОВНОГО РОЗВИТКУ МОЛОДШИХ ШКОЛЯРІВ З ОСОБЛИВИМИ ОСВІТНІМИ ПОТРЕБАМИ
}

\author{
Ю. Д. Бойчук \\ д. пед. н., професор, проректор з наукової роботи \\ Харківського національного педагогічного університету імені Г. С. Сковороди \\ О. С. Казачінер \\ д. пед. н., доценти кафедри здоров’я людини, реабілітолоігї і спеціальної психології \\ Харківського національного педагогічного університету імені Г. С. Сковороди

\section{О. В. Мірошниченко} \\ к. пед. н., помічник проректора з наукової роботи \\ Харківського національного педагогічного університету імені Г. С. Сковороди
}

\section{Н. В. Науменко}

к. пед. н., викладач кафедри педагогіки та психології Національного фармацевтичного університету (м. Харків)

Одним із пріоритетних завдань розвитку вітчизняної освіти є подальше удосконалення практики навчання та виховання дітей, зокрема молодших школярів, з особливими освітніми потребами, розв'язання актуальних проблем, наявних у цій сфері. Однією з таких проблем є забезпечення духовного розвитку цієї категорії учнів, під час якого всі учасники освітнього процесу можуть отримати умови для найбільш ефективної реалізації збережених та корекції порушених функцій.

Суспільство в цілому тільки виграє, якщо вчасно і ефективно сприятиме усебічному духовному розвитку дітей з особливими потребами за допомогою видів діяльності, які дозволять їм перебувати в психологічно комфортному для них середовищі.

Саме у віці 6-10 років закладається фундамент моральної поведінки, відбувається засвоєння моральних норм поведінки, починає формуватися суспільна спрямованість особистості. Дитина знаходиться у тісній емоційній взаємодії з учителем. Почуття та емоції відіграють значну роль у навчальній роботі. Тому духовний розвиток має стати невід'ємним компонентом освіти дітей із нозологіями, однією з умов їхнього соціокультурного розвитку. Забезпечення духовного розвитку сприяє розв'язанню завдань успішної соціалізації та духовно-особистісного зростання молодших школярів шляхом формування в них духовнозбережувальної компетенції.

Діти з особливостями психофізичного розвитку часто відчувають труднощі в оцінюванні своїх і чужих вчинків. Схвалення, заохочення для них є показниками правильності їхніх учинків або поведінки. Осуд, упереджене ставлення, особливо колективне, можуть стати сильними методами впливу, ними слід користуватися з урахуванням індивідуальних особливостей дітей.

У закладах загальної середньої освіти слід прагнути попередити, запобігти неправильним вчинкам вихованців. Цьому мають сприяти чітка організація діяльності, визначення обов'язків кожного учня, вибір ефективних шляхів виховної роботи. Основним шляхом духовного розвитку дітей з особливими освітніми потребами є комплексний підхід до навчання і виховання.

У зв’язку з цим виникає потреба в переосмисленні концептуальних підходів до забезпечення духовного розвитку молодших школярів з особливими освітніми потребами; в перегляді основних завдань і змісту духовного-етичного та естетичного виховання у початковій школі.

На основі визначеної мети постають такі завдання дослідження:

- Здійснити аналіз науково-педагогічної літератури з проблеми забезпечення духовного розвитку молодших школярів з особливими освітніми потребами.

- Визначити зміст, форми, методи та прийоми забезпечення духовного розвитку молодших школярів з особливими освітніми потребами.

- Окреслити перспективи подальших наукових пошуків у напрямі цієї проблеми.

Теоретико-методологічні основи дослідження духовного здоров'я та розвитку учнів закладено в наукових розвідках Ю. Бойчука і Н. Науменко [2]. У праці Т. Гужанової, Н. Рудницької проаналізовано шляхи впливу художньо-естетичної діяльності на духовний розвиток молодших школярів. Виховання здоров'язбережувальної поведінки молодших школярів засобами українських народних традицій було досліджено О. Мірошниченко [14]. У дослідженні Н. Науменко розкрито суть поняття «моральність», «духовність» та «духовне здоров'я», а також розглянуто вплив духовності на збереження і зміцнення духовного здоров'я [15].

А. Задорожним виховання духовності у структурі ціннісно-смислової картини світу визначено як цілеспрямований процес впливу на особистість молодшого школяра з метою формування таких якостей: довіра, 
милосердя, вдячність, співчуття, чуйність, щирість, доброта, любов, ввічливість, толерантність, самокритичність, терпимість, тактовність, делікатність, повага, справедливість [10].

У свою чергу Ю. Польшиною [18] проаналізовано поняття «духовність», «цінність», «духовні цінності», «моральні цінності». Визначено роль загальноосвітнього закладу у формуванні духовних цінностей школярів. Наведено основні умови, що впливають на формування духовних цінностей школярів.

М. Гончаренко та Ю. Бойчуком досліджується взаємодія людини як біопсихосоціальної істоти, з навколишнім середовищем з урахуванням прямих і зворотних зв'язків цієї взаємодії. Авторами викладено нові підходи до забезпечення зміцнення здоров'я, духовної еволюції людини [5].

Має місце досить велика кількість студіювань окремих аспектів навчання, виховання та розвитку дітей 3 особливими освітніми потребами [11]. Так, вивченню тенденцій духовного розвитку молодших школярів та їхнього впливу на роботу з дітьми з особливими освітніми потребами присвячені наукові праці І. Гладченко, М. Супрун [4], I. Демченко [9], I. Кулик [12], Kaili C. Zhang, Deirdra I-Hwey [19; 20] та інших.

У процесі вивчення та аналізу літератури про духовно-моральне виховання $[13 ; 16 ; 17]$ було визначено сутнісні аспекти духовно-морального виховання дітей із обмеженими фізичними можливостями. Цей педагогічний процес спрямовано на корекцію вторинних недоліків шляхом формування духовних потреб, засвоєння духовних цінностей, моральних норм, які реалізуються в соціальній поведінці. Процес $є$ двобічним та поєднує педагогічний вплив із внутрішнім прагненням до самовдосконалення.

Таким чином, в усьому прогресивному світі і в Україні зокрема науковці та практики прагнуть глибоко проаналізувати потреби та можливості духовного розвитку як школярів у цілому, так і учнів початкової ланки щодо оптимізації перебування в суспільстві людей з особливими потребами. Проте, на жаль, відчувається недостатня кількість таких досліджень.

Тому наразі особливої актуальності набуває питання забезпечення духовного розвитку молодших школярів саме з особливими освітніми потребами.

Роль морального виховання, а також духовного розвитку дітей з особливими освітніми потребами велика, оскільки це сприяє профілактиці правопорушень, дозволяє формувати духовний світ (ціннісні орієнтири) та моральні риси такої дитини, дозволяючи їй органічно вписатися в суспільство; розкриває творчий потенціал, розширюючи можливості професійного вибору; формує наполегливість у праці, сприяє підвищенню професійної орієнтації, сприяє зниженню кількості безробітних, виховує працелюбність (добровільне ставлення до праці та чесність), формує у свідомості дитини поняття праці як загальнолюдської цінності; дозволяє скоротити кількість неблагонадійних родин; дозволяє розв'язати проблему соціального інфантилізму.

Ще В. Сухомлинський постійно приділяв увагу важливій, гострій і складній проблемі — вихованню і навчанню дітей з особливими потребами [1;3].

На думку вченого, дітей з особливими потребами потрібно навчати в масовій загальноосвітній школі, оскільки це необхідно для того, щоб діти з обмеженими можливостями перебували в атмосфері повноцінного духовного життя школи. На уроці таким дітям слід давати завдання, які б гарантували їм успіх у виконанні, а відповідно і відчуття радості успіху.

У численних педагогічних працях В. Сухомлинський постійно звертає увагу на індивідуалізацію роботи з такими дітьми, оскільки бачив конкретну роботу педагога у визначенні причини біди в кожному окремому випадку, необхідності знайти кожній дитині посильну розумову працю, доступні шляхи подолання труднощів, залучати дитину до цікавої роботи, щоб вона могла розвиватися інтелектуально, на основі почуття власної гідності $[1 ; 3]$.

Справжній гуманізм ставлення до дітей з розумовими обмеженнями полягає у створенні сприятливих умов для їхнього життя, навчання й розвитку. Якщо з ранніх років дитина з обмеженими можливостями постійно уникає розв'язання проблемних ситуацій, то в неї формується толерантність до свого становища.

У роботі з дітьми з особливими потребами широко використовують так звані методи корекції, до яких належать: заохочення й покарання, попередження, заміна інтересів тощо.

Міцний учнівський колектив і гармонійні стосунки між вихователями і вихованцями будуть тоді, коли особливі дітки не залишені самі на себе, а розвиваються в таких же умовах, що й здорові діти. В. Сухомлинський вважав, що колектив може стати виховним середовищем тільки в тому разі, коли він створюється під час спілкування і спільної діяльності, яка дає кожному радість і впевненість.

Однією з умов розвитку в учнів навичок спілкування є забезпечення необхідного мовленнєвого середовища, головними організаторами якого, в першу чергу, є педагоги. Тільки через мовленнєву діяльність, сприйняття мовлення інших і власне говоріння діти оволодівають мовою як засобом спілкування й пізнання. Найкраще мовленнєві ситуації з розумово відсталими дітьми створювати у процесі гри.

На думку В. Сухомлинського, гармонійний і всебічний розвиток особистості можливий тільки там, де два вихователі - школа і сім'я - не тільки діють разом, висувають однакові вимоги перед дитиною, а ще й $є$ однодумцями, дотримуються єдиних принципів, не мають розбіжностей у цілях, методах і засобах виховання [1]. 
Проте ускладнення проблеми морального виховання, в тому числі й духовного розвитку дітей з особливими освітніми потребами, визначається наступними чинниками:

- браком дослідження теми морального виховання дітей з ООП, оскільки немає спеціальних програм у заданому напрямку (саме для дітей з особливими освітніми потребами);

- д діти з особливими освітніми потребами відрізняються різноманітними порушеннями психофізичного розвитку. У дитини внаслідок перенесених захворювань порушується нормальний перебіг процесів сприймання, запам'ятовування, відтворення. Багатьом учням властива наявність серйозних порушень у сфері збудження, неврівноважена поведінка. Ненормальне функціонування вказаних процесів не дозволяє дитині засвоювати складну систему знань про світ.

Під час роботи над проблемами духовного розвитку молодших школярів з особливими освітніми потребами необхідно брати до уваги їхні вікові та педагогічні особливості:

- Схильність до гри. В умовах ігрових стосунків дитина добровільно вправляється, засвоює нормативну поведінку. В іграх до дитини висувається вимога до дотримання правил. Так дитина вчиться рахуватися з іншими, отримує уроки справедливості, чесності, правдивості.

- Неспроможність тривалий час займатися монотонною діяльністю.

- Брак чіткості моральних уявлень у зв'язку з невеликим досвідом. Ураховуючи досвід дітей, норми моральної поведінки можна поділити на 3 рівні: дитина до 5 років засвоює примітивний рівень правил поведінки, що грунтується на забороні чи запереченні: «Не розмовляй голосно», «Не перебивай тих, хто розмовляє», «Не чіпай чужі речі», «Не кидай сміття» тощо. Немає сенсу говорити про другий рівень морального виховання, якщо перший не опановано. Але саме ця суперечка спостерігається серед підлітків: вони хочуть сподобатися оточуючим людям, але не опанували елементарну правильну поведінку. На 3 рівні (до 14-15 років) підлітки оволодівають принципом: «Допомагай оточуючим людям!».

Може бути наявна суперечка між знанням, як треба, і практичним застосуванням (це стосується етикету, правил хорошого тону, спілкування).

Вважаємо, що в ході організації процесу духовно-морального виховання дітей з ООП та підвищення його ефективності мають бути враховані базові принципи, які лежать в основі інклюзії: цінність людини не залежить від її здібностей та досягнень; кожна людина здатна відчувати й думати; кожна людина має право на спілкування і на те, щоб бути почутою; усі люди потребують один одного; справжня освіта має здійснюватися лише в контексті реальних стосунків; усі люди потребують підтримки та дружби ровесників; різноманіття підсилює всі сторони життя людини.

О. Декіна, досліджуючи питання психолого-педагогічної підтримки батьків, які виховують дітей з ООП [8], що, в свою чергу, є одним із напрямів духовного розвитку цих дітей, визначає іiі основні завдання: допомога батькам у прийнятті своїх дітей такими, які вони $\epsilon$, озброєння батьків різними способами комунікації, допомога у формуванні адекватної оцінки психологічного стану дітей, зняття тривоги та страху відторгнення, допомога у позбавленні від комплексу провини й неповноцінності своїй та своєї родини тощо. На думку автора, їхнє практичне впровадження сприятиме зниженню ризиків соціальної дезадаптації прийомних дітей, підвищенню цінності відповідального батьківства та батьківської компетентності. Уважаємо, що розв'язання зазначених завдань також позитивно відобразиться на забезпеченні духовного розвитку дітей з особливими освітніми потребами.

I. Гладченко вважає, що реалізація напряму з формування духовнозбережувальної компетенції в дітей із порушеннями психофізичного розвитку забезпечує [4]:

1) формування духовності за допомогою літератури, засобів масової інформації;

2) формування уявлень про норми поведінки християнина засобами ігрової та практичної діяльності;

3) розвиток естетичного сприйняття шляхом ознайомлення дітей із елементами православної культури (архітектурою, іконописом, святами);

4) виховання в дітей дбайливого ставлення та почуття благоговіння до святинь;

5) формування сімейних цінностей у дітей, християнського ставлення до батьків, близьких, рідного краю, природи, Батьківщини;

6) прищеплення любові до традицій родини;

7) формування потреби в здоровому способі життя, прищеплення навичок відповідальності за власне здоров'я, профілактика шкідливих звичок;

8) розвиток потенційних здібностей дітей;

9) створення соціальних і матеріальних умов для духовного розвитку особистості дитини.

І. Гладченко вважає, що проблема пошуку та вибору педагогічної стратегії духовно-оздоровчого виховання дітей з ООП потребує запровадження технології формування духовно-моральних основ особистості дитини з порушеннями психофізичного розвитку (формування духовнозбережувальної компетенції, розвиток духовно-етичної сфери, когнітивних процесів, формування уявлень про душу, духовно-моральні цінності, якості, 
усвідомлення християнсько-моральних норм поведінки тощо). Це, у свою чергу, на думку автора, сприятиме утворенню цілісного педагогічного уявлення стосовно зазначеного напряму спеціальної дошкільної освіти та підвищенню ефективності процесу ранньої соціалізації шляхом формування духовнозбережувальної компетенції в дітей з порушеннями психофізичного розвитку [4].

Таким чином, на основі власного педагогічного досвіду роботи з учнями молодшого шкільного віку, серед яких були ті, що мали особливі освітні потреби і навчалися разом із однолітками типового розвитку в класах закладів загальної середньої освіти, а також викладацької роботи з учителями початкових класів у системі післядипломної освіти нами визначено такі форми, методи та прийоми забезпечення духовного розвитку таких школярів:

На уроках:

Нетрадиційні уроки: «Дивись не забудь, людиною будь!» (Урок доброти), уроки гарної поведінки «Ми та наші вчинки» та інші.

Читання та аналіз творів дитячої художньої літератури: оповідання й казки В. Сухомлинського: «Як Сергійко навчився жаліти», «Горбатенька дівчинка», «Розділена радість», «Найгарніша мама», «Добре слово», «Бо я - людина», «Сьома дочка», «Хто кого веде додому», «Яблуко в осінньому саду», «А серце тобі нічого не наказало?», «Іменинний обід», «Склянка води», «Щоб ти став кращим», «Суниці для Наталі», «Красиві слова і красиве діло» та інші; В. Нестайко «Злочин Жори Горобейка», «Авіа, пташиний диспетчер» О. Лущевської («Грані-Т», 2014), оповідання В. Катаєва «Квітка-семиквітка», оповідання Н. Красоткіної «Думи наші, думи», «Зірочка», «Івасик малює дощ», «Неправильна казка, або невигадана історія про одну дівчинку», «Один день спілкування з мудрою людиною» та інші.

У позакласній діяльності:

Перегляд, аналіз та обговорення змісту мультиплікаційних фільмів, які навчають дитину толерантнос$m i$ : Подарунок» (Німеччина), «Маленька каструлька Анатоля», «Секрет Маела», «Мій братик з Місяця» (Франція), «Акуратна історія» (Росія), «Струни» (Іспанія), «Про Дмитрика» (Росія), «Тамара» (США), мультфільмів, які навчають норм моральної поведінки: «Про дівчинку, яка наступила на хліб», «Ключ», «Казка старого дуба», «Жовтий лелека», «Брати Лю», «Горіховий прутик» та інші.

Перегляд, аналіз та обговорення художніх фільмів для дітей: «Опудало», «Бабусин онук», «Новенька», «Киш та Двапортфелі» та інші.

Бесіди: «Шкідливі звички», «Духовне здоров’я», «Культурна людина», «Про культуру спілкування», «Про культуру поведінки за столом», «Те, що знаєш, і те, що вмієш, за плечима не носити», «Сім кольорів щастя», «Світ навколо тебе. Довкілля», «Учися бачити красу», «Велетні-чарівники, Весняний спів землі», «Краса навколо тебе, Шануй сам себе, шануватимуть і люди тебе», «Доброта і жорстокість», «Усмішка, наче сонечко», «Учись себе перемагати», «Ледащо не годиться нінащо», «Важко тому жити, хто не хоче робити» та інші.

Тренінгові заняття: «Країна Доброти», «Що є добре, що - погано», «Ти живеш серед людей», «Класний колектив дружбою міцний» та інші

Виховні заходи: «Я вірю в силу доброти», «Учись у дружбі жити», «Доброта - це краса людської душі», «Бути на Землі Людиною», «Чарівні слова», «Скажи — «НІ!» булінгу», «Слова вітання та прощання», «Чесність і правдивість», «Шануй людей — i тебе шануватимуть», «Неси добро у світ природи», «Чарівні слова відкривають серця» та інші.

Години спілкування: «Великодні дзвони» та інші.

Висновки з проведеного дослідження полягають у тому, що у зв’язку із загальною тенденцією зростання інтересу до людини, iї внутрішнього світу, на початку ХХІ століття змінюється розуміння суті, інакше починає оцінюватися значення гуманістичного підходу до досліджень проблеми інклюзіі дитини із порушеннями розвитку у життя суспільства. Забезпечення духовного розвитку дітей з особливими потребами є одним із завдань сучасної системи освіти. Тому діти з особливими потребами, зокрема молодшого шкільного віку, внаслідок притаманних їм особливостей потребують створення особливих умов для їхнього духовного розвитку, оптимального та позитивного для них, їхніх родин та суспільства в цілому.

Необхідними формами, методами та прийомами духовного розвитку таких дітей на уроках є перегляд, аналіз, обговорення змісту, дій та вчинків героїв літературних творів, дитячих кінофільмів, мультиплікаційних фільмів, у яких порушується проблема толерантності, моральної поведінки, «інакшості», різноманіття, а також систематичне проведення різноманітних позакласних заходів, виховних годин, тренінгів, бесід тощо з питань духовності.

Перспективами подальшого студіювання в напрямі окресленої проблеми ми вважаємо висвітлення особливостей духовного розвитку дітей з особливими освітніми потребами середнього та старшого шкільного віку, а також студентів за окремими нозологіями. Наразі необхідною має стати розробка практичних рекомендацій для вчителів, асистентів учителів, вихователів закладів дошкільної освіти, фахівців у галузі спеціальної педагогіки та психології, викладачів закладів вищої освіти щодо забезпечення духовного розвитку дітей та молоді з особливими освітніми потребами. 


\section{Література}

1. Арцишевський Р. А. В. О.Сухомлинський про духовний розвиток молодших школярів // Пед. дискурс : зб. наук. пр. 2011. Вип. 10. С. 14-21.

2. Бойчук Ю. Д., Науменко Н. В. Підготовка майбутніх учителів до формування духовного здоров’я молодших школярів: теоретико-методичні аспекти : монографія. Х. : ФОП Мезіна В. В., 2018. 128 с.

3. Василь Сухомлинський про роботу з дітьми з особливими потребами. URL: http://lviv.samopomich.ua/ vasylsuhomlynskyj-pro-robotu-z-ditmy-z-osoblyvymy-potrebamy.

4. ладченко I. В., Супрун М. О. Формування духовнозбережувальної компетенції в дітей з порушеннями психофізичного розвитку в умовах дошкільного корекційно-розвивального простору. URL: http:// lib.iitta.gov.ua/708028/1/\%D0\%B7\%D0\%B1\%20KDA22_\%D0\%A1.\%20303-309.pdf.

5. Гончаренко М. С., Бойчук Ю. Д. Екологія людини : навчальний посібник / за ред. Н. В. Кочубей. Суми : ВТД «Університетська книга»; К. : Видавничий дім «Княгиня Ольга», 2005. 394 с.

6. Гужанова Т. С., Рудницька Н. Ю. Вплив художньо-естетичної діяльності на формування духовності молодших школярів // Вісн. Житомир. держ. ун-ту ім. І. Франка. 2005. Вип. 21. С. 38-40.

7. Гурнік Л. Сучасні вимоги до виховання дітей з особливими освітніми потребами. URL: http://www.stattionline.org. ua/pedagog/106/19910-suchasni-vimogi-do-vixovannya-ditej-z-osoblivimi-osvitnimi-potrebami.html.

8. Декина Е. В. Особенности психолого-педагогической подготовки специалистов к работе с замещающей семьей, воспитывающей детей с особыми потребностями в развитии // Современные проблемы науки и образования. 2015. № 5. URL: http://www.science-education.ru/ru/article/view?id=22499.

9. Демченко I. Навчання, виховання і творчий розвиток учнів інклюзивної початкової школи в інтерактивній грі // Психолого-педагогічні проблеми сільської школи. 2014. Вип. 49. С. 48-54.

10. Задорожний А. В. Розвиток поняття «духовність» у структурі ціннісно-смислової картини світу // Педагогіка вищ. та серед. шк. : зб. наук. пр. 2012. Вип. 34. С. 245-251.

11. Казачінер О. С. Інноваційні педагогічні технології навчання дітей з особливостями розвитку. Х. : Основа, 2018.96 с.

12. Кулик I. В. Формування культури родинних взаємин в процесі духовного виховання молодших школярів шкілінтернатів // Педагогіка, психологія та мед.-біол. пробл. фіз. виховання і спорту. 2006. № 10. С. 53-56.

13. Меньшиков В. М. Воспитание в Западной Европе и России: смыслы и направления развития. Курск : Курск. гос. ун-т, 2008. $188 \mathrm{c}$.

14. Мірошниченко О. М. Виховання здоров'язбережувальної поведінки молодших школярів засобами українських народних традицій : дис. ... канд. пед. наук : 13.00.07. Старобільськ : ЛНУ ім. Тараса Шевченка, 2018.313 с.

15. Науменко Н. В. Формування духовності як запорука збереження та зміцнення духовного здоров'я // Науковий часопис НПУ імені М. П. Драгоманова. Серія 16. Творча особистість учителя: проблеми теорії і практики : зб. наук. праць. К. : Вид-во НПУ імені М. П. Драгоманова, 2013. Вип. 22 (32). С. 29-33.

16. Ожиганова Г. В. Психологические аспекты духовности. Часть І. Духовный интеллект // Психологический журнал. 2010. № 4. T. 31. С. 21-34.

17. Пашков С. В. Духовно-нравственное воспитание в системе современного российского образования : дисс. ... канд. пед. наук: 13.00.01. Курск, 2010. 191 с.

18. Польшина Ю. Ю. До проблеми формування духовних цінностей молодших школярів // Проблеми інж.-пед. освіти. 2012. № 36. С. 219-222.

19. Kaili C. Zhang Spirituality and Disabilities: Implications for Special Education // Intellectual and Developmental Disabilities: August 2010. Vol. 48. № 4. P. 299-302.

20. Kaili C. Zhang, Deirdra I-Hwey Wu Nurturing the spiritual well-being of children with special needs. URL: http://mistie. cogbill.net/files/9013/7894/9916/Religion_Disabilities_Child_80026295.pdf. 